\title{
Substitution Trial of Red Seaweed (Porphyra) With Green Grass Jelly (Cyclea Barbata Miers) in Making Nori
}

\author{
Mohammad Syaltut Abduh ${ }^{1}$, Alifatqul Maulana ${ }^{2}$ and Sinta Haditsah Zaitun ${ }^{3}$ \\ ${ }^{1,2,3}$ Sekolah Tinggi Pariwisata Trisakti, Jakarta, Indonesia \\ Email : Syaltut86@gmail.com and alifatqul@stptrisakti.ac.id,
}

\begin{abstract}
This study aims to utilize seaweed as a substitute on Japanese Nori foodstuffs and can be consumed by the community. Seaweed is a raw material that is widely used for various purposes such as additional ingredients on cosmetics or or just made in addition to the drink on ice mix. With this research is expected to seaweed in the making of Nori can be replaced with green grass jelly. Because Japanese food such as Nori is now commonly found in almost all major cities in Indonesia. The method used is an experimental method which will be making products with the trial of the treatment of the control over the products studied were Nori. After conducting experiments then performed using the Sensory Testing instrument in the form of a questionnaire about Organoleptik Test and Test hedonic committed to the panelists, to find out the differences as well as the level of preference on taste, texture and aroma. Descriptive test was then performed to give a snapshot of data from Appearance and hedonic test has been done. Then do the data analysis using the Test Independent T-test to determine significant differences between the arithmetic mean of the control and treatment products.
\end{abstract}

\section{Keywords - Trial, Seaweed, Green Grass Jelly, Nori}

\section{INTRODUCTION}

The prospect of seaweed in the future is quite good, given the potential of Indonesian waters is still large enough for the cultivation of these commodities (Anonymous, 1991). With the increasingly widespread food industry growing in accordance with the advancement of the era, it will take a lot of raw materials, especially abundant in Inodensia as for example; seaweed. Food derived from seaweed is still a little not even in though maximally and in large quantities. This plant is of high economic value in the food and non-food industries (cosmetic, textile and pharmaceutical industries), to meet domestic and foreign demand (Indriani and Sumiarsih 1992 in Tri Handayani, 2004).

The benefits of seaweed as a food have long been known. In Indonesia seaweed has long exploited beach residents for vegetables, vegetables, pickles, cakes, puddings, and sweets. One of the edible seaweed is Sargassum sp. Which is the largest brown algae (Phaeophyta) in the tropical seas.Nori is the Japanese name for food in the form of dried seaweed sheets. Nori is used as a decoration and flavoring of various Japanese dishes, side dishes while eating rice, and snack foods. The main raw material comes from Porphyra which belongs to the class of red seaweed, such as Porphyra pseudolinearis Ueda is known as Iwanori and Porphyra yezoensis Ueda. Nori is a seaweed that is thin and dry sheets. After seaweed is processed then widely used as food that is consumed directly.

According to the Indonesian Seaweed Association (ARLI) of 555 species of seaweed found in Indonesia, only 3 species are able to be cultivated. Among them are Glacilaria, Eucheuma Cotonii, and Eucheuma Spinosum (m.tempo.com). Meanwhile, the raw materials needed for the manufacture of nori is the red sea weed type Porphyra. Indonesia is still one of the countries that import nori. Although many local fishermen have become nori producers, they can not meet the market demand for consuming nori. Along with the many nori demand in Indonesia, the local people make this as an advantage by making nori from materials that are widely cultivated in Indonesia such as, spinach leaves, and cassava leaves. 
However, when viewed from the texture of seaweed that has a gel there is a plant in Indonesia that can be used to substitute seaweed in the manufacture of nori is green cincau leaves. The leaves commonly used in the manufacture of ice cincau it turned out to have many content that bermafaat for the human body.

\section{LITERATURE REVIEW}

Nori is dried or roasted seaweed sheets (Korringa 1976), whereas according to Giury (2006), nori is one of dried seaweed processed and processed products of red seaweed (Rhodophyta). Nori is a food consumed after being dried and roasted (Kuda et al., 2004). The Japanese have consumed nori since the 8th century. The highest nori consumer is Japan as much as $75 \%$ of total seaweed production. Japan, China and Korea are the largest nickel producing countries today, shown by the total nori production data of 2 billion sheets / year.

There are 555 types of seaweed in Indonesia, 21 species of which have been used as food and have economic value and trade commodity. These species are agar-producing groups Gracillaria sp, Gelidium sp, Gelidiella sp and Gelidiopsis sp, and Carrageenan-producing groups Eucheuma spinosum and Hypnea sp (Aslan, 1991).

1. Green Seaweed (Chlorophyceae)

2. Seaweed Chocolate (Phaeophyceae)

3. Red Seaweed (Rhodophyceae)

The ring is gel that resembles gelatin obtained from the process of soaking the leaves (or other organs) of certain plants in water. Gelter form because the plant leaves contain carbohydrates that are able to bind water molecules. The word cincau itself comes from the Hokkien sienchau dialect commonly pronounced among Chinese in Southeast Asia. Ring itself in the original language is actually the name of the plant (Mesona spp.) Which is the material for making this gel. The ring is most widely used as the main component of a refreshing drink (for example in ice cincau or ice mix). Reportedly also cincau have the effect of conditioning and peluruh.

According to Agus Ruhyanat and Taryono, (2002) the green grass jelly are divided into three types found in Indonesia, namely:

1. Black grass jelly (Mesona Palustris)

2. Green grass jelly (Cyclea Barbata Miers)

3. Shurbs grass jelly (Melastoma polyanthum)

Green grass jelly from the leaves can be made gelatin a green color rather bright and efficacious to treat high blood, fever, and abdominal bloating. This root can be used as a medicine for fever and abdominal pain. Green ring can be propagated by seed, stem cuttings, and root buds. The gel on the green cincau leaves is formed because the plant leaves contain carbohydrates that are able to bind water molecules. 
TABLE 1. NUTRITION CONTENT OF NORI

\begin{tabular}{cc}
\hline Nutritions & $\begin{array}{c}\text { Nori / 100gr } \\
\text { (Dry Seaweed) }\end{array}$ \\
\hline Calories (cal) & 35 \\
Protein (g) & $21-47$ \\
Fat (g) & 0,3 \\
Carbohidrate (g) & 12,20 \\
Sodium (mg) & 48 \\
Potassium (mg) & 356 \\
Vitamin A (\%) & 104 \\
Vitamin B 6 (\%) & 10 \\
Vitamin C (\%) & 65 \\
Calsium (\%) & 7 \\
Iron (\%) & 9
\end{tabular}

Source : dawezynski et al. 20117

TABLE 2. NUTRITION CONTENT OF GREEN GRASS JELLY

\begin{tabular}{cc}
\hline Nutritions & Green Grass Jelly/100gr \\
\hline Energy (calories) & 122 \\
Protein $(\mathrm{g})$ & 6 \\
Fat $(\mathrm{g})$ & 1 \\
Carbohydrate $(\mathrm{g})$ & 26 \\
Fiber & 48 \\
Potassium (mg) & 6,23 \\
Vitamin A (SI) & 107,50 \\
Vitamin B 1 (mg) & 80 \\
Vitamin C (mg) & 17 \\
Calsium (g) & 0,1 \\
Iron (g) & 0,0033 \\
\hline
\end{tabular}

\section{METHODS}

The research method used in this research is experimental method. According to Kusmayadi and Endar Sugiarto (2000: 30), the experimental method is done by the method of manipulation or treatment of the independent variable of the object being studied, then observing, measuring and analyzing the effect of such manipulation.

Organoleptic tests or sensory tests are the means of testing using the human senses as the primary means of measuring the reception power of the product. Hedonic Test or Preferred Test is a test method to measure the level of preference to a product.To process and analyze the data obtained from checklist, SPSS software (statistic package for the social science) is used. The type of test used is the Independent T-test. 


\section{RESULTS AND DISCUSSION}

The organoleptic test is a test based on the sensing process. Organoleptic tests use the human senses to measure the texture, aroma, and taste of a food product. According to ebookpangan.com (2006), there are three types of organoleptic test, namely discriminative test, descriptive test, and affective test. Differentiation test to check whether there are differences among the examples presented. The description test is used to determine the nature and intensity of the difference. Both of the above test groups require trained or experienced panelists. While affective test is based on the measurement of favorite (or hedonic) or relative level of measurement. Affective testing that tests the likes and / or receipts of a product requires the number of untrained panelists that are often considered to represent certain consumer groups. Type of organoleptic test used in this research is descriptive test and hedonic test. The descriptive test is performed by 5 expert panelists while the hedonic test is performed by 5 expert panelists and 20 unstructured panelists but often consume japanese food to find out whether there are differences in taste, texture, and aroma between nori made using red seaweed with nori made with leaves green grass jelly. Test scale used by scoring method with highest score 4 and lowest 1 to assess the intensity of each parameter.

\subsection{Ingredients and Tools}

TABLE 3.INGREDIENTS

\begin{tabular}{llcc}
\hline No & Ingredients & Control & Green Grass Jelly \\
\hline $\mathbf{1}$ & Red Seawed & $10 \mathrm{gr}$ & - \\
2 & Green Grass Jelly & - & $10 \mathrm{gr}$ \\
\hline
\end{tabular}

TABLE 4. TOOLS

\begin{tabular}{|c|c|c|}
\hline No & Tools & Qty \\
\hline 1 & Cloth & 1 \\
\hline 2 & Bowl & 1 \\
\hline 3 & Knife & 1 \\
\hline 4 & Spoon & 1 \\
\hline 5 & Frame & 1 \\
\hline 6 & Cutting Board & 1 \\
\hline
\end{tabular}




\subsection{Making Process of Nori}

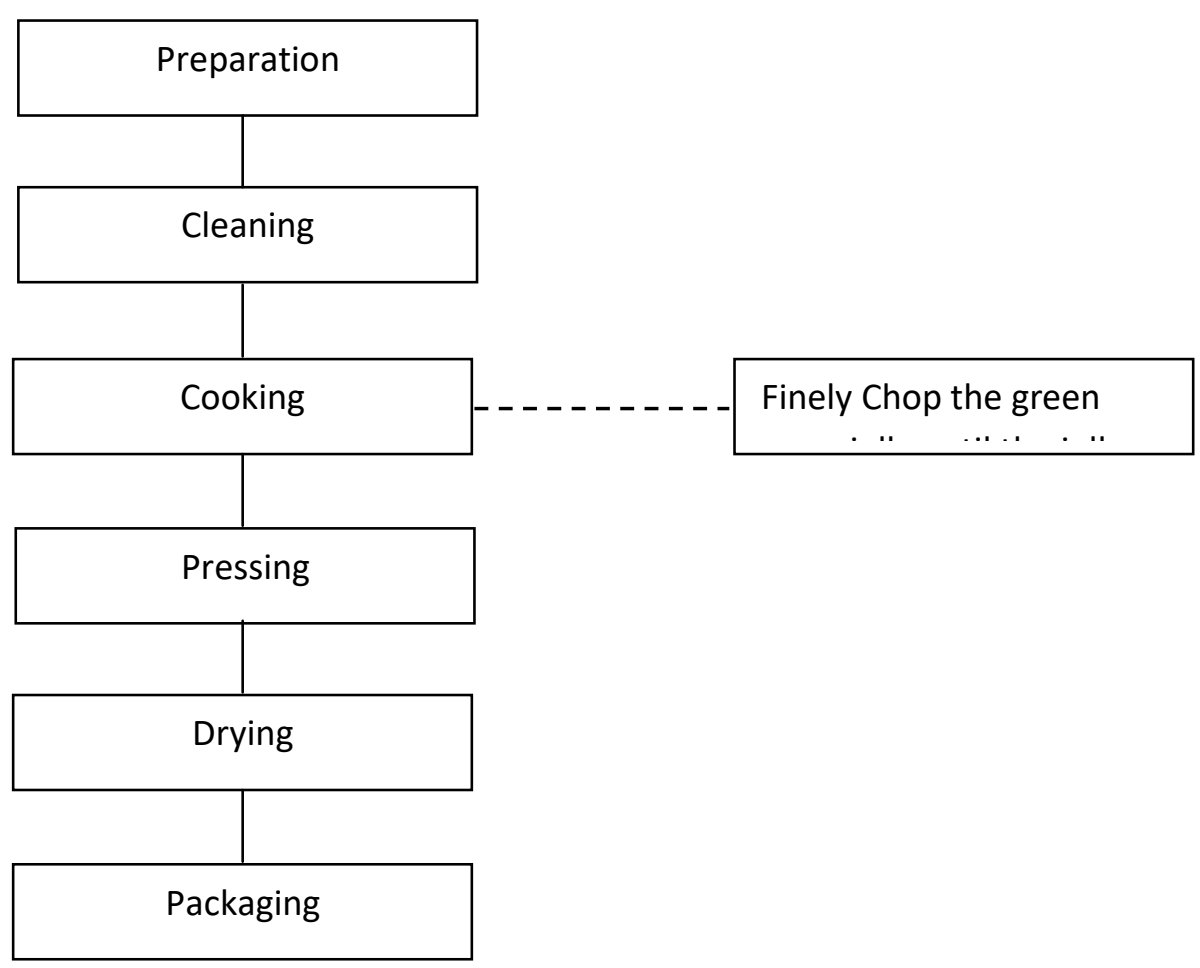

Fig 1. The process of making nori with red seaweed and green grass jelly 
TABLE 5. HEDONIC TEST HYPOTHESIS

\begin{tabular}{|c|c|c|c|c|c|c|c|c|c|c|}
\hline \multicolumn{11}{|c|}{ Independeat Samples Test } \\
\hline & & \multicolumn{2}{|c|}{$\begin{array}{l}\text { Levene's Teut for } \\
\text { Equaliey of Variances }\end{array}$} & \multicolumn{7}{|c|}{ t-test for Equality of Means } \\
\hline & & $\mathrm{F}$ & sig. & , & dt & $\begin{array}{l}\text { Sig.(2- } \\
\text { taled) }\end{array}$ & \begin{tabular}{|c|} 
Mean \\
Difference
\end{tabular} & \begin{tabular}{c|} 
Sid. \\
Emor \\
Difteren \\
ce
\end{tabular} & \multicolumn{2}{|c|}{$\begin{array}{l}95 \% \text { Confidesce } \\
\text { Interval of the } \\
\text { Differeace }\end{array}$} \\
\hline \multirow{2}{*}{ Hedonic Tatte } & $\begin{array}{l}\text { Equal variances } \\
\text { astumed }\end{array}$ & .100 & 753 & 6.904 & 48 & .000 & .960 & .139 & $\$ 80$ & 1.240 \\
\hline & $\begin{array}{l}\text { Equal variances not } \\
\text { assumed }\end{array}$ & & & 6.904 & 47.190 & .000 & .900 & .139 & .080 & 1.240 \\
\hline \multirow{2}{*}{ Hedonic Aroma } & $\begin{array}{l}\text { Equal variances } \\
\text { assumed }\end{array}$ & 1.638 & .207 & 2.529 & 48 & .015 & .400 & .174 & .090 & 790 \\
\hline & $\begin{array}{l}\text { Equal variances not } \\
\text { assumed }\end{array}$ & & & 2.529 & 47.512 & .015 & .40 & .174 & .090 & 790 \\
\hline \multirow{2}{*}{ Hedonic Texture } & $\begin{array}{l}\text { Equal variances } \\
\text { assumed }\end{array}$ & .340 & .563 & 7.612 & 48 & .000 & 1.040 & .137 & 765 & 1.315 \\
\hline & $\begin{array}{l}\text { Equal variances not } \\
\text { assumed }\end{array}$ & & & 7.612 & 47.961 & .000 & 1.040 & .137 & .705 & $1.31 \mathrm{~s}$ \\
\hline
\end{tabular}

Viewed from the table, it can be pulled hypothesis in terms of taste, aroma and texture where all three have significant value $<0.05$ which means Ho is rejected which means there is a real difference between the panelist's favorite level on the control with the treatment in each taste, texture and aroma. 
TABLE 6. DESCRIPTIVE TEST HYPOTHESIS

\begin{tabular}{|c|c|c|c|c|c|c|c|c|c|c|}
\hline \multicolumn{11}{|c|}{ Independent Samples Test } \\
\hline & & \multicolumn{2}{|c|}{$\begin{array}{c}\text { Levene's Test for } \\
\text { Equality of } \\
\text { Variances }\end{array}$} & \multicolumn{7}{|c|}{$t$-test for Equality of Means } \\
\hline & & \multirow[t]{2}{*}{$F$} & \multirow[t]{2}{*}{ Sig. } & \multirow[t]{2}{*}{$t$} & \multirow[t]{2}{*}{ df } & \multirow[t]{2}{*}{$\begin{array}{l}\text { Sig. (2- } \\
\text { tailed) }\end{array}$} & \multirow[t]{2}{*}{$\begin{array}{c}\text { Mean } \\
\text { Differen } \\
\text { ce }\end{array}$} & \multirow[t]{2}{*}{$\begin{array}{l}\text { Std. } \\
\text { Error } \\
\text { Differ } \\
\text { ence }\end{array}$} & \multicolumn{2}{|c|}{$\begin{array}{l}95 \% \text { Confidence } \\
\text { Interval of the } \\
\text { Difference }\end{array}$} \\
\hline & & & & & & & & & Lower & Upper \\
\hline \multirow{2}{*}{ Taste } & $\begin{array}{l}\text { Equal variances } \\
\text { assumed }\end{array}$ & .000 & 1.000 & 3.464 & 8 & .009 & 1.200 & .346 & .401 & 1.999 \\
\hline & $\begin{array}{l}\text { Equal variances not } \\
\text { assumed }\end{array}$ & & & 3.464 & 8.000 & .009 & 1.200 & .346 & .401 & 1.999 \\
\hline \multirow{2}{*}{ Aroma } & $\begin{array}{l}\text { Equal variances } \\
\text { assumed }\end{array}$ & .000 & 1.000 & 3.536 & 8 & .008 & 1.000 & .283 & .348 & 1.652 \\
\hline & $\begin{array}{l}\text { Equal variances not } \\
\text { assumed }\end{array}$ & & & 3.536 & 8.000 & .008 & 1.000 & .283 & .348 & 1.652 \\
\hline \multirow{2}{*}{ Texture } & $\begin{array}{l}\text { Equal variances } \\
\text { assumed }\end{array}$ & .000 & 1.000 & 2.887 & 8 & .020 & 1.000 & .346 & .201 & 1.799 \\
\hline & $\begin{array}{l}\text { Equal variances not } \\
\text { assumed }\end{array}$ & & & 2.887 & 8.000 & .020 & 1.000 & .346 & .201 & 1.799 \\
\hline
\end{tabular}

Viewed from the table, it can be pulled hypothesis in terms of taste, aroma and texture where all three have significant value $<0.05$ which means Ho is rejected which means there is a real difference between the controls with the treatment in each part taste, texture and aroma.

After seeing the results and discussion of research obtained from the test hedonic and organoleptic test of 25 panelists, it can be obtained answers to the hypothesis that has been made. Furthermore, it will be explained about the results of experiments on the manufacture of control nori using 100\% red seaweed and nori treatment using $100 \%$ green grass leaves in terms of taste, aroma and texture assessment obtained from observations made during the research process.

Although the research has shown there is a significant difference between nori control and nori treatment in terms of taste, aroma and texture penelitipada organoleptik test and hedonic test. Judging from the results of the panelists that nori research using green leaves of treatment rings as a viable material to be continued. It can be strengthened from the nutrient content of green grass jelly that has more benefits and easy to find in the environment so as to facilitate the production of nori green grass jelly. And some opinions from the panelists are as follows.

In terms of taste between nori control and nori treatment has a very different taste. This is due to the control nori that uses red seaweed as the basic ingredients have a distinctive taste of the sea when eaten such as the flavor of fish and the natural saltiness caused by iodine from seawater. While the taste of nori treatment using the basic ingredients of green grass jelly has a tasteless flavor without further processing in giving perisa so that the taste of nori treatment is less favored by panelists.

In terms of the scent between nori control and nori treatment has a very different aroma. This is caused by control nori that uses red seaweed as the basic ingredients have a distinctive aroma of the sea while the nori treatment using green grass jelly still has the scent of leaves. For that try to heat nori treatment of green grass jelly on the pan fry to help the evaporation of water and aroma unpleasant on green grass jelly nori.

In terms of texture between nori control and nori treatment has a very different texture. This is due to the different types of materials used. Red seaweed has a subtle texture so it does not greatly affect the end result of the control nori. While nori treatment of green grass jelly have a rather large and coarse fiber. Therefore the result of nori treatment is more rough than nori control. 


\section{CONCLUSIONS}

1. From the research that has been done it has been proven that green grass jelly can be used as red seaweed substitution in the manufacture of nori although it takes longer in the drying process.

2. There is a difference in taste, flavour, and texture between red seaweed nori with green grass jelly nori.

3. Panelists prefer the nori with red seaweed compared to the substitution nori leaves of green grass jelly in terms of taste, flavour and texture.

\section{REFERENCES}

Chapman VJ. 1970. Agar-agar in Seaweeds and Their Uses. London: Methew and Co.Ltd.151-195p. Chapman VJ. 1970. Agar-agar in Seaweeds and Their Uses. London: Methew and Co.Ltd.151$195 p$.

Chapman VJ, Chapman DJ.1980. Seaweed and their uses. In Production and Untilization of Product from Commercial Seaweed. Roma: FAO Fisheries Technical Paper.

Darmadi, Hamid. (2013). Metode Penelitian Pendidikan dan Sosial. Bandung : Alfabeta

Dawezynski C, Rainer S, Gerhard J. 2007. Amino acids, fatty acids and dietary fibre in edible seaweed product. J. Food Chem. 103:891-899.

Emzir. 2010. Metodologi Penelitian Pendidikan:Kuantitatif dan Kualitatif. Jakarta: Rajawali Pers.

Food And Agriculture Organization Of The United Nations (FAO)., 2008, The State of Food and Agriculture, Rome.

Korringa, P., 1976. Farming Marine Organisms Low In Food Chain (A Multidisciplinary Approach to Edible Seaweed, Mussel, and Clam Production). New York: Elsevier Science Publishing Company.

Kuda T, Hishi T, Maekawa S. 2005. Antioxidant properties of dried product of "Habanori" an edible brown alga, Petalonioa binghamiae (J. Agardh) Vinogradova. J. Food Chem. 98:545-550.

Mchugh, D.J., 2003, A Guide To Seaweed Industry, Food and Agric. Org. of the Un, Rome.

Winarno FG. 1996. Teknologi Pengolahan Rumput Laut. Jakarta: PT. Gramedia Pustaka Utama. 